the auditor of Poweshiek County, who has furnished me many facts and figures, I learn that trappers speak of a white variety, counted by them particularly wary and hard to catch.

One caught in Grinnell was marked with hinder parts white and fore parts brown.

To those who have not seen the porket gopher, it may be well to state that they are a small rodent of about the same color as, and perhaps a shade larger than, the domestic rat.

They have no external ears, have small bead-like eyes, a short tail, and powerful fore-legs, armed with strong claws for digging; and, what is very characteristic, they have large extensible cheek pouches or pockets. The presence of the gopher is made known to you by its mounds of earth, about the size of large ant-hills, rather than by its own presence, for it is rarely indeed that they are seen.

University of Nebraska.

ERwin H. Barbour.

\section{WIND-STORMS AND TREES.}

Two very severe wind-storms have recently swept over Iowa which injured trees of all kinds, but especially some of the conifers. I have no record of the velocity of the wind in the storm of several weeks ago. It was less severe, however, than the one of last Friday. According to the weather office observations as reported in the Iowa State Register of April 2, the maximum speed was sixty-four miles an hour at 2 P.M. in Des Moines, Iowa. The gale started at daybreak, "By 11 the wind had reached an average velocity of fifty miles an hour, and it was approaching the danger-point. It kept gradually increasing until 2 P.M., when the wind-gauge at the top of the Federal building swung around to an average velocity of sixty-four, with sudden flaws above the 100-point." The weather observer, Mr. Schaffer, states that at the period of its greatest velocity the amount of pressure thrown against houses, glass, etc., was fifty pounds per square foot. The wind on Friday came from the south-west, and later shifted to the west. The severe wind-storm of several weeks ago came from the north. As usual in storms of this kind old and poorer branches fell readily, and trees suffered severely in consequence of the injury because of the many open wonnds. I shall give a few illustrations how different trees were affected. On the college grounds, there are cultivated a large number of European as well as native trees. A few old trees were blown down, but these were partly decayed in the interior. Both gales seem to have been hard on some of the conifers. In some cases the ground was strewn with green leaves and short branches. In point of greatest injury Norway spruce (Picea excelsa) stands first. The branches broken off varied from one to six years' growth, mostly two and three years. It is also noticeable that many of the branches did not break at the beginuing of the year's growth but in the middle. In many cases the branches are stripped of their leaves in the direction of the wind, - south, west, and north sides of the tree. The Scotch pine (Pinus sylvestris) is also affected, but in this case branches only, as a rule, were severed from the plant. The branches vary from one to six years' growth, occasionally more, but mostly within this limit. The same tendency to snap off in the middle of the year's growth may be observed. Few leaves were blown off.

Black spruce (Picea nigra) stands next. Some branches and leaves were broken off, though not nearly as many as in the other species.
White spruce (Picea alba) was also affected, but it seems. able to stand the severity of the wind much better than the Norway spruce and Scotch pine. It is followed closely by the Hemlock (Abies Canadensis), -injury mostly confined to the leaves. There is only a single tree on the ground, which grows in a somewhat less exposed place than the white and Norway spruce, so that it may not be a fair test.

Red, or Norway pine (Pinus resinosa), some branches blown off and but few leaves. White pine (Pinus strobus), few leaves, a number of branches.

Balsam Fir (Abies balsamea) has suffered less than any of the above, a few branches were blown off.

Austrian pine (Pinus Austriaca) and Dwarf Mountain. pine ( $P$. pumilio) have lost few leaves and branches. The red cedar (Juniperus Virginiana) should be classed with it. An occasional branch of Larix europoea and L. laricium. may be found.

On the whole, the deciduous trees have fared better than the evergreens. Some species of willows (Salix) have lost many branches. The cottonwood (Populus monilifera) and soft maple (Acer saccharinum) bave lost some. branches. Honey locust (Gleditschia triacunthes, hackberry (Celtis occidentalis), hard maple (Acer barbatum), green ash (Fraxinus viridis), Cratogus punctata have not. suffered.

Iowa Agricultural College, Ames. L. H. Pamarel.

\section{RUSSIAN SUNFLOWER INDUSTRY.}

THE sunflower, as a garden plant, bas been known all over Russia for many years, but only in certain districts has it been cultivated on a large scale as an industry. The first. cultivation of sunflower seed for commercial purposes began, says the United States Consul General, at St. Petersburg, in 1842 , in the village of Alexeievka, in the district of Berutchinsk, government of Voronezh, by a farmer who was the first to obtain oil from the seed. This farmer soon found many followers, and the village of Alexeievka soon became the centre of the new industry. The government of Voronezh is even now the chief district in European Russia for the growing of the sunflower. Besides the district of Berutchinsk, this plant is cultivated on a large scale in the districts of Novokhopersk; Ostrogoshk, Bobroosk; Valouisk and Korotoiaks. From the government of Voronezh the cultivation of sunflowers spread to the adjacent governments of Tamboo and Saratov, where there are large fields cultivated with this plant, particularly in the latter government. The people of the province of the Don and the governments of Simbersk and Samara are more or less engaged in this trade, in fact in the entire south east of Russia the sunflower furnishes a prominent product of the farm. Two kinds of sunflower are grown in Russia - one with small seeds; used for the production of oil, and the other with larger seeds; consumed by the people in enormous quantities as dainties. In the district where the seed is cultivated on a large scale, the plant has been continually grown on the same soil for many years in succession, thus producing a special disease of the plant. The sunflower seed is used principally for obtaining sunflower oil, which, owing to its, nutritious qualities, purity, and agreeable flavor, has superseded all other vegetable oils in many parts of the country. In general, the cultivation of the sunflower in Russia is considered to be very profitable. At the average $y$ ield of 1,350 pounds to the acre, and at the average price of $\frac{3}{4} \mathrm{~d}$. a pound, the farmer receives an income of about $£ 4$ an acre, and this income can 